\title{
PENINGKATAN KEMAMPUAN BERPIKIR PESERTA DIDIK MENGGUNAKAN PROBLEM-BASED LEARNING
}

\author{
Karmila Suryani $^{1}$, Ade Fitri Rahmadani ${ }^{2}$, Andi Gautama ${ }^{3}$ \\ ${ }^{1,2}$ Pendidikan Teknik Informatika dan Komputer, Fakultas Keguruan dan Ilmu Pendidikan, \\ Universitas Bung Hatta, Jalan Bagindo Aziz Chan, Aie Pacah, Padang - 25586 \\ ${ }^{3}$ Teknik Komputer dan Jaringan SMK Muhammadiyah 1 \\ Jalan By Pass KM 6 Lubuk Begalung, Padang - 25145 \\ 1e-mail: karmila.suryani@bunghatta.ac.id
}

\begin{abstract}
Abstrak
Revolusi industri 4.0 secara tidak langsung mengharuskan kemampuan berpikir kritis tingkat tinggi. Penelitian bertujuan untuk meningkatkan kemampuan berpikir kritis peserta didik dengan penerapan model Problem-Based Learning (PBL). Metode penelitain yang digunakan adalah Penelitian Tindakan Kelas (PTK) melalui 2 siklus pembelajaran. Penelitian merupakan penelitian populasi dengan jumlah 16 orang siswa Teknik Komputer dan jaringan (TKJ) SMK Muhammadiyah 1 Padang. Teknik pengumpulan data menggunakan tes hasil belajar dan eknik analisis data menggunakan deskriptif. Hasil penelitian yang diperoleh pada siklus 1 adalah kemampuan berpikir kritis peserta didik memperoleh nilai sebesar $62 \%$ pada kategori tuntas dengan nilai rata-rata yaitu 74 , nilai tertinggi 88 dan nilai terendah 50. Sementara pada siklus 2 terjadi peningkatan dengan ketuntasan nilainya sebesar $100 \%$, nilai rata-rata yaitu 79 , nilai tertinggi 85 , dan nilai terendah 75 . Berdasakan hasil penelitian, maka dapat disimpulkan bahwa terjadi peningkatan kemampuan berpikir kritis peserta didik dengan menggunakan model PBL.
\end{abstract}

Kata Kunci: berpikir kritis, Problem-Based Learning, PTK.

\begin{abstract}
The industrial revolution 4.0 indirectly requires high-level critical thinking skills. The research aims to improve students' critical thinking skills by applying the ProblemBased Learning (PBL) model. The research method used was Classroom Action Research (CAR) through 2 learning cycles. The research is a population study with a total of 16 students of Computer and Network Engineering (TKJ) SMK Muhammadiyah 1 Padang. Data collection technique using test and data analysis technique using descriptive. The results obtained in cycle 1 are the students' critical thinking skills scored $62 \%$ in the complete category with an average value of 74 , the highest value of 88 and the lowest value of 50. While in cycle 2 an increase with $100 \%$ completeness is a value, the average value is 79 , the highest value is 85 , and the lowest value is 75. Based on the results of the research, it can be concluded that an increase in students' critical thinking skills using the PBL model.
\end{abstract}

Keywords: critical thinking, Problem-Based Learning, CAR.

\section{PENDAHULUAN}

Pemerintah Indonesia dalam menghadapi revolusi industri 4.0 telah mengupayakan untuk melakukan berbagai perubahan di segala bidang, tidak terkecuali bidang pendidikan. Dampak dari industri 4.0 yaitu menumbuhkan kreativitas, inovasi, inklusivitas, dan keberlanjutan (Buasuwan, 2018). Diperlukan 
pengembangan jaringan pembelajaran, keterlibatan antara publik-swastamasyarakat, pola pikir baru, keterampilan guru, peserta didik, dan teknologi baru. Guna mempersiapkan peserta didik dalam bekerja, maka harus dibekali berbagai keterampilan, seperti keterampilan beradaptasi, berpikir kritis, inovatif, dan akuntabilitas (Bhattacharyya, 2018; Feldman, 2010).

Berbagai tantangan dan kondisi bermunculan dalam menghadapi revolusi 4.0, yaitu: (1) Kondisi kompetisi global yang mengharuskan adanya kesadaran global dan kemandirian; (2) Kondisi kerja sama global dengan mengutamakan kemampuan bekerja sama, penguasaan information communication and technology (ICT); (3) Pertumbuhan informasi yang mengharuskan memiliki kemampuan untuk menguasai teknologi, critical thinking, dan pemecahan masalah; (4) Perkembangan kerja dan karier tidak terlepas dari perlunya critical thinking dan pemecahan masalah, inovasi dan penyempurnaan, serta fleksibel dan adaptable; (5) Perkembangan ekonomi berbasis pelayanan jasa, knowledge economy yang memerlukan informasi, critical tinking, dan pemecahan masalah (Wolf, et al., 2018).

Salah satu upaya pemerintah Indonesia untuk mengiringi kondisi yang muncul adalah dengan melakukan perubahan terhadap kurikulum (Gentili, 2017). Dalam membangun kurikulum di sekolah, maka peran sentral guru adalah berkolaborasi dengan perusahaan dan lembaga lain sehingga kurikulum yang diciptakan dapat berjalan dengan baik. Lahirnya Kurikulum 2013 memberikan penekanan kepada guru untuk lebih meningkatkan kompetensi pedagogik, yaitu mengembangkan kemampuannya dalam menginovasi pembelajaran yang akan diterapkan. Secara tidak langsung, guru harus menguasai pendekatan ilmiah (saintifik) dengan 5M, yaitu: mengamati (observing), menanya (questioning), menalar (associating), mencoba (experimenting), dan membentuk jejaring (networking) dalam pembelajarannya (Hosnan, 2014).

Landasan utama dari pengembangan kurikulum adalah adanya indikasi kurang bervariasinya model pembelajaran yang disajikan guru kepada peserta didik. Problematika tersebut telah mengarah pada rendahnya hasil belajar dan kualitas kemampuan peserta didik dalam berpikir kritis. Hal tersebut terlihat dari 
hasil pretest yang diperoleh peserta didik hanya 13\% dengan kategori tuntas. Suatu kelas dikatakan tuntas belajar secara klasikal jika persentasi yang dicapai sekurang-kurangnya 80\% (Usman, 2010).

Setiap guru dalam proses pembelajaran berupaya untuk menyampaikan materi dengan menggunakan metode yang sesuai dengan karakteriatik mata pelajaran yang diajarkan. Hal tersebut bertujuan agar kemampuan berpikir kritis peserta didik menjadi baik. Namun yang terjadi berdasarkan hasil pengamatan langsung oleh peneliti pada peserta didik Teknik Komputer dan Jaringan (TKJ) kelas XI Sekolah Menengah Kejuruan (SMK) Muhammadiyah 1 Padang teridentifikasi beberapa permasalahan sebagai berikut: (1) Guru belum menerapkan model pembelajaran yang bervariasi; (2) Peserta didik tidak telibat langsung dalam proses pembalajaran; (3) Kurangnya sarana dan prasarana pendikung di dalam kelas; (4) Peserta didik lebih menyukai kegiatan praktikum dari pada pembelajaran teori; dan (5) Kurangnya kemampuan berpikir kritis peserta didik.

Proses pembiasaan peserta didik untuk memiliki keterampilan berpikir kritis dalam menyelesaikan setiap persoalan yang dihadapinya, maka guru sebaiknya dapat mendesain pembelajaran yang menarik melalui model pembelajaran yang dierapkan. Salah satu model pembelajaran yang tepat digunakan yaitu ProblemBased Learning (PBL) atau pembelajaran berbasis masalah. PBL menekankan belajar sebagai proses yang melibatkan pemecahan masalah dan berpikir kritis dalam konteks yang sebenarnya (Muah, 2016). PBL memberikan kesempatan kepada peserta didik untuk mempelajari hal-hal yang lebih luas yang berfokus pada mempersiapkan peserta didik untuk menjadi warga negara yang aktif dan bertanggung jawab (Rubiah, 2016). Melalui PBL peserta didik memperoleh pengalaman dalam menangani masalah yang realistis dan menekankan pada penggunaan komunikasi, kerja sama, dan sumber-sumber yang ada untuk merumuskan ide dan mengembangkan keterampilan dalam berpikir secara kritis.

Beberapa hasil penelitian menunjukkan bahwa penerapan PBL dapat meningkatkan hasil belajar peserta didik (Setyorini, dkk., 2011; Nurun, 2014; Repi, 2019; Silaban, 2019), serta model pembelajaran PBL berpengaruh terhadap 
hasil belajar peserta didik (Ihsan, 2019; Rusman, 2015; Work dan Mauffette, 2018). Berdasarkan beberapa hasil penelitian tersebut, disimpulkan bahwa model pembelajaran PBL dapat meningkatkan hasil belajar dan kemampuan berpikir kritis peserta didik. Model PBL sangat baik diterapkan dalam proses pembelajaran di kelas, khususnya dalam mengukur kemampuan berpikir kritis peserta didik.

Pelaksanaan model pembelajaran PBL dilakukan melalui Penelitian Tindakan Kelas (PTK). PTK merupakan pilihan yang menarik bagi para guru, staf administrasi sekolah, dan pemangku kepentingan pendidikan lainnya untuk meningkatkan kinerja sektor pendidikan (Mills, 2011). PTK merupakan alat yang efektif untuk membantu guru dan pendidik lainnya mengungkap strategi yang pas untuk meningkatkan praktik mengajar (Sagor, 2004). PTK akan melewati beberapa siklus sampai semua peserta didik dinyatakan tuntas atau terjadi peningkatan terhadap hasil belajarnya (Slameto, 2016). Peningkatan kemampuan kompetensi pedagogik guru akan terjadi apabila melakukan PTK, sehingga akan berdampak pada aktivitas dan hasil belar peserta didik (Navi, 2018).

\section{METODE}

Jenis penelitian yang digunakan adalah penelitian tindakan kelas (PTK) dengan prosedur yang dikembangkan oleh Mukhlis (2011). PTK terdiri atas komponen perencanaan, tindakan, pengamatan, dan refleksi yang selanjutnya memungkinkan diikuti dengan siklus spiral, yaitu studi pendahuluan sebelum melakukan tindakan. Adapun prosedur dari PTK adalah sebagai berikut: (1) Perencanaan (planning), yaitu menyusun rencana tindakan yang akan dilakukan untuk meningkatkan keterampilan berpikir kritis dan hasil belajar peserta didik melalui penerapan model PBL. Perencanaan dimulai dari mempersiapkan jadwal pembelajaran PBL, RPP, perangkat pembelajaran PBL, persiapan peralatan, media pembelajaran, dan sosialisasi pembelajaran PBL kepada peserta didik; (2) Pelaksanaan (action), yaitu kegiatan pembelajaran yang dilakukan berdasarkan rencana yang telah disepakati sebelumnya antara peneliti dengan guru mitra. Tindakan tersebut dilakukan untuk memperbaiki keadaan atau proses pembelajaran dan hasil belajar peserta didik; (3) Observasi (observation), yaitu 
kegiatan mengamati, mengenali sambil mendokumentasikan (mencatat dan merekam) terhadap proses, hasil, pengaruh, dan masalah baru yang mungkin saja muncul selama tindakan dilakukan. Hasil observasi akan dijadikan bahan analisis dan dasar refleksi terhadap tindakan yang telah dilakukan dan bagi penyusunan rencana tindakan selanjutnya; (4) Refleksi (reflection), yaitu mengevaluasi tentang apa-apa saja rencana dan tindakan yang sudah tercapai dan apa yang belum dapat dan sempat dilakukan pada suatu siklus. Refleksi dilakukan secara kolaboratif antara peneliti dengan guru mitra. Berdasarkan dari hasil refleksi, peneliti bersama guru mitra merumuskan kembali rencana pembelajaran untuk ditindaklanjuti pada siklus berikutnya.

Penelitian dilaksanakan pada Juli sampai dengan Oktober 2019 yang bertempat di SMK Muhammadiyah 1 Padang, Sumatera Barat. Sementara subjek penelitian adalah peserta didik kelas IX TKJ semester ganjil 2018/2019. Instrumen penelitian menggunakan tes hasil belajar berupa soal essay dan objektif berbasis Higer Order Thinking Skills (HOTS) untuk mengukur kemampuan berpikir kritis peserta didik. Data yang diperoleh adalah nilai dari kemampuan berpikir kritis peserta didik melalu tes yang diberikan dalam 2 siklus. Teknik analisis data menggunakan pengolahan data deskriptif, yaitu mencari persentase nilai yang diperoleh peserta didik.

\section{HASIL DAN PEMBAHASAN}

Penelitian bertujuan untuk meningkatkan kemampuan berpikir kritis peserta didik dengan menerapkan model pembelajaran PBL melalui penelitian tidakan kelas. Data diperoleh berdasarkan nilai tes yang diberikan pada setiap siklus.

\section{Siklus 1}

\section{Perencanaan}

Sebelum terlaksananya proses pembelajaran pada siklus 1, perlu dipersiapkan terlebih dahulu silabus, perangkat pembelajaran (RPP), lembar kerja siswa (LKS), dan soal tes. 


\section{Pelaksanaan}

Proses pembelajaran pada siklus 1 diawali dengan memberikan soal pretest yang bertujuan untuk mengukur kemampuan awal peserta didik. Soal pretest terdiri dari 15 butir objektif yang sudah bersifat HOTS. Setelah diketahui kemampuan awal peserta didik melalui nilai yang dihasilkan selanjutnya peserta didik dibagi menjadi 4 kelompok yang terdiri dari 4 orang peserta didik. Pembagian kelompok dilakukan dengan cara menempatkan peserta didik berdasarkan hasil pretest, yaitu anggota kelompok terdiri dari 1 orang dengan kemampuan rendah, 1 orang dengan kemampuan tinggi,serta 2 orang dengan kemampuan sedang. Tujuan dibentuknya kelompok berdasarkan tingkat kemampuan peserta didik adalah agar peserta didik bisa saling bertukar pendapat dan berdiskusi tentang materi pelajaran yang diberikan. Hasil pretest mata pelajaran Teknologi Jaringan Luas yang diperoleh oleh peserta didik terlihat pada Tabel 1.

Tabel 1 Nilai Pre Test

\begin{tabular}{ccc}
\hline Jumlah Peserta Didik & Persentase (\%) & Keterangan \\
\hline 14 & 87 & Tidak Tuntas \\
2 & 13 & Tuntas \\
\hline
\end{tabular}

Berdasarkan data pada Tabel 1, terlihat bahwa dari 16 peserta didik yang melakukan pretest, hanya 2 orang (13\%) yang memperoleh nilai dengan kategori tuntas, selebihnya tidak tuntas. Hal tersebut diduga karena peserta didik kurang terbiasa dengan menjawab soal-soal yang bersifat HOTS. Berdasarkan permasalahan tersebut, maka diterapkanlah model pembelajaran PBL dengan metode diskusi dan simulasi, selanjutnya dilakukan pembelajaran untuk siklus 1 .

Pelaksanaan pembelajaran untuk siklus 1 dilakukan sebanyak 4 kali tatap muka dengan waktu masing-masing tatap muka adalah 4 jam pelajaran yaitu $4 \times 45$ menit. Peserta didik diberikan sebuah kasus yang dikerjakan secara berkelompok dengan cara berdiskusi dan melakukan simulasi packet tracer dalam perancangan jaringan WAN. Peserta didik dipersilahkan untuk membuat jaringan WAN menggunakan 14 komputer, 1 buah router, serta access point. Setelah peserta didik berhasil membuat jaringan tersebut, maka peserta didik melakukan koneksi 
antar-jaringan menggunakan protocol jaringan. Masing-masing kelompok mencatat dan melaporkan semua permasalahan yang ditemui selama simulasi.

Peserta didik menemukan solusinya sesuai dengan referensi yang jelas secara ilmiah. Masing-masing kelompok mempresentasikan hasil diskusinya di depan kelas, selanjutnya menyimpulkan pembelajaran yang telah terjadi.

\section{Pengamatan}

Hasil analisis data yang diperoleh melalui tes hasil belajar peserta didik pada siklus 1 terlihat pada Tabel 2 .

Tabel 2 Hasil Kemampuan Berpikir Kritis Peserta Didik Siklus 1

\begin{tabular}{ccc}
\hline Jumlah Peserta Didik & Persentase $(\boldsymbol{\%})$ & Keterangan \\
\hline 6 & 38 & Tidak Tuntas \\
10 & 62 & Tuntas \\
\hline
\end{tabular}

Berdasarkan data pada Tabel 2, terlihat bahwa ada perubahan terjadi peningkatan jumlah peserta didik dengan kategori tuntas, namun masih ada beberapa siswa yang belum tuntas. Pembelajaran dengan model PBL dikatakan berhasil jika indikator keberhasilan telah tercapai yaitu $80 \%$ pesera didik tuntas nilai KKM (Usman, 2010). Data tersebut menunjukkan bahwa indikator keberhasilan telah terpenuhi. Namun, ketuntasan dari peserta didik masih $62 \%$, oleh karenanya pembelajaran dilanjutkan pada siklus 2 .

\section{Refleksi}

Bererapa hal yang menjadi catatan bagi peneliti selama pelaksanaan siklus 1 yaitu kurangnya kekompakan peserta didik dalam melakukan simulasi karena yang mengerjakan hanya 1 orang saja. Peserta didik juga kurang bisa menganalisis permasalahan yang ditemukan sehingga laporan dan hasil diskusinya belum sesuai dengan yang diharapkan. Oleh karenanya, peneliti memberikan motivasi agar peserta didik setiap kelompok mampu untuk membuat jaringan WAN dengan cara memberikan beberapa permainan yang berhubungan dengan materi. Setelah peserta didik melakukan pemainan tersebut, maka muncul semangat dan keinginaan untuk belajar. Proses selanjutnya adalah pembelajaran pada siklus 2 . 


\section{Siklus 2}

\section{Perencanaan}

Pelaksanaan perencanaan pada siklus 2, yaitu mempersiapkan bahan-bahan yang diperlukan agar proses pembelajaran dengan menerapkan model PBL dapat berjalan sesuai yang direncanakan. Tahap perencanaan terlebih dahulu mempersiapkan silabus, perangkat pembelajaran (RPP), lembar kerja siswa (LKS), serta beberapa instrumen pendukung lainnya.

\section{Pelaksanaan}

Siklus 2 dilaksanakan sebanyak tiga kali pertemuan. Peserta didik dipersilakan untuk duduk sesuai dengan kelompoknya masing-masing. Selanjutnya guru memberikan materi dan menayangkan video dan game yang berkaitan dengan materi pembelajaran, kemudian peserta didik mengamati dan berdiskusi dengan kelompoknya dalam menyelesaikan masalah yang diberikan oleh guru. Setelah selesai mendapatkan solusi dari permasalahan yang diberikan, maka masing-masing kelompok mempresentasikan hasil diskusinya di depan kelas. Setelah selesai mempresentasikan, semua peserta didik bersama guru membuat kesimpulan dari materi yang dipelajari. Kegiatan tersebut dilakukan dalam 3 kali pertemuan dengan rincian waktu yaitu untuk 1 kali tatap muka dilaksanakan selama 4 jam pelajaran.

\section{Pengamatan}

Hasil berpikir kritis peserta didik diperoleh berdasarkan tes hasil belajar. Kemampuan berpikir kritis peserta didik pada siklus 2 terlihat pada Tabel 3 .

Tabel 3 Hasil Kemampuan Berpikir Kritis Peserta Didik Siklus 2

\begin{tabular}{ccc}
\hline Jumlah Peserta Didik & Persentase $(\boldsymbol{\%})$ & Keterangan \\
\hline 0 & 0 & Tidak Tuntas \\
16 & 100 & Tuntas \\
\hline
\end{tabular}

Berdasarkan data pada Tabel 3 terlihat bahwa kemampuan berpikir kritis peserta didik melalui tes hasil belajar semuanya tuntas. Hal tersebut dikarenakan tindakan yang dilakukan setelah proses refleksi pada siklus 1. Proses pembelajaran dilaksanakan dengan memberikan permainan sehingga meningkatkan semangat peserta didik dalam melakukan pembuatan jaringan 
melalui simulasi Packet Tracer. Peserta didik secara bergantian melakukan percobaan sehingga mengetahui permasalah yang terjadi dan mendapatkan solusinya sendiri. Kegiatan pembelajaran berhenti pada siklus 2. Perbandingan nilai mulai dari pretest, siklus 1, dan siklus 2 terlihat pada Tabel 4.

Tabel 4 Perbandingan Ketuntasan Nilai Peserta Didik

\begin{tabular}{lcc}
\hline & Tuntas & Tidak Tuntas \\
\hline Pretest & $13 \%$ & $87 \%$ \\
Siklus 1 & $62 \%$ & $38 \%$ \\
Siklus 2 & $100 \%$ & $0 \%$ \\
\hline
\end{tabular}

Berdasarkan data pada Tabel 4 terlihat bahwa persentase ketuntasan hasil belajar peserta didik sudah mengalami peningkatan, mulai sari siklus 1 sampai siklus 2. Peningkatan yang terjadi pada dari nilai pretest di siklus 1 sebesar $49 \%$. Sementara peningkatan yang terjadi sampai siklus 2 mencapai $87 \%$, sehingga semua peserta didik dinyatakan tuntas. Apabila peserta didik yang berkontribusi pada diskusi kelompok selama pembelajaran, maka mendapatkan hasil yang baik (Vickery, 2013; Work dan Mauffett, 2018).

Perbandingan perolehan nilai berdasarkan nilai rata-tara, nilai tertinggi, dan nilai terendah terlihat pada Tabel 5.

Tabel 5 Perbandingan Nilai Pretest, Siklus 1, dan Siklus 2

\begin{tabular}{cccc}
\hline Kriteria & Pretest & Siklus 1 & Siklus 2 \\
\hline Nilai Rata-rata & 41 & 74 & 79 \\
Nilai Tertinggi & 80 & 88 & 85 \\
Nilai Terendah & 15 & 50 & 75 \\
\hline
\end{tabular}

Berdasarkan data pada Tabel 5 terlihat bahwa terjadi perubahan rata-rata nilai peserta didik pada masing-masing siklus. Perolehan nilai tertinggi terdapat pada siklus 1, namun masih ada beberapa dari peserta didik yang belum tuntas sehingga dilakukan siklus 2 dengan perolehan nilai semua peserta didik dinyatakan tuntas $100 \%$. Kemampuan berpikir kritis sangat dibutuhkan oleh peserta didik dalam pelaksanaan pembelajaran di kelas (Fauziah, 2018; Kusnadi, dkk., 2017). Penerapan model pembelajaran bebasis masalah dapat meningkatkan hasil belajar peserta didik (Neriasari dan Ismawati, 2018; Shultz and Li, 2016; Yane, 2016; Rohani dan Farlina, 2016; Eviliyanto dan Nurekawati, 2016). 
Berdasarkan hasil penelitian dan pembahasan, maka PBL merupakan salah satu model yang cocok digunakan oleh guru untuk memfasilitasi peserta didik meningkatkan kemampuan berpikir kritis.

\section{SIMPULAN}

Berdasarkan hasil penelitian, maka dapat disimpulkan bahwa penerapan model PBL dapat meningkatkan kemampuan berpikir kritis peserta didik yang dilakukan melalui 2 siklus PTK, dengan rincian: (1) Perolehan nilai ketuntasan peserta didik pada siklus 1 sebesar $62 \%$ dengan nilai rata-rata yaitu 74 , nilai tertinggi 88, dan nilai terendah 50; dan (2) Perolehan nilai pada siklus 2 ketuntasanya sebesar $100 \%$ dengan nilai rata-rata yaitu 79 , nilai tertinggi 85 , dan nilai terendah 75 .

\section{UCAPAN TERIMA KASIH}

Ucapan terima kasih diucapkan kepada Kemrisktekdikti yang telah memberi bantuan Penugasan Dosen ke Sekolah (PDS) pada tahun 2019 dan Sekolah Menengah Kejuruan (SMK) Muhammadiyah 1 Padang sebagai mitra pelaksanaan program PDS.

\section{DAFTAR PUSTAKA}

Bhattacharyya, E. 2018. Stakeholders Perspective on Communicative Competence in Industry 4.0: Walk the Talk of Informative Technologists. SHS Web of Conferences 53, 03001(2018): ICHSS 2018. Hal: 1-12.

Buasuwan, P. 2018. Rethinking Thai Higher Education for Thailand 4.0. Asian Education and Development Studies, 7(2): 157-173.

Eviliyanto \& Nurekawati, E. E. 2016. Penerapan Model Problem Based Learning terhadap Hasil belajar Mahasiswa Semester 5 Program Studi Pendidikan Geografi. Edukasi: Jurnal Pendidikan, 14(2): 212-222.

Fauziah, U. 2018. Problem Based Learning Terintegrasi Karakter Religius pada Materi Sistem Reproduksi Manusia. Jurnal Pendidikan Informatika dan Sains, 7(1): 91-106.

Feldman. D. A. 2010, Berpikir Kritis, Strategi untuk Pengambilan Keputusan. Jakarta: PT Indeks.

Gentili, C. 2017. "Time Out" for Classical Studies? The Future of Italian Liceo Classico in the 4.0 World. Journal Estudios Sobre Educación, 33(2017): 127-143. 
Hosnan, M. 2014. Pendekatan Saintifik dan Kontekstual dalam Pembelajaran Abad 21. Bogor: Ghalia Indonesia.

Ihsan, 2019. Pengaruh Model Pembelajaran Problem-Based Learning terhadap Peningkatan Keterampilan Berpikir Kritis Siswa Kelas X IPS SMA N 1 Suralaga Tahun Pelajaran 2018/2019. Jurnal Media Biana Ilmiah, 14(6): 45-49.

Kusnadi, E., Martini, E., \& Nugraha, G. N. 2017. Konstruk Pembelajaran Pendidikan Kewarganegaraan Berbasis Masalah untuk Meningkatkan Kemampuan Berpikir Kritis Peserta Didik. Jurnal Pendidikan Kewarganegaraan, 1(2): 150-163.

Mills, G. E. 2011. Action Research A Guide for the Teacher Researcher (4th ed.). Boston: Pearson.

Muah, T. 2016. Penggunaan Model Pembelajaran Problem-Based Instruction (PBI) untuk Meningkatkan Keaktifan dan Hasil Belajar Matematika Siswa Kelas 9B Semester Gasal Tahun Pelajaran 2014/2015 SMP Negeri 2 Tuntang - Semarang. Jurnal Scolaria, 6(1): 41-53.

Mukhlis, A. 2011. Penelitian Tindakan Kelas. Konsep Dasar dan LangkahLangkah, Surabaya: Unnesa.

Neriasari, D. P. \& Ismawati, E. 2018. Pengaruh Penggunaan Model Pembelajaran Problem Based Learning terhadap Hasil Prestasi Belajar Menulis Eksplanasi Ditinjau dari Aspek Motivasi Belajar Siswa. Jurnal Pendidikan Bahasa, 7(2): 436-447.

Nurun, Y. N. 2014. Penerapan Model Problem-Based Learning untuk Meningkatkan Keterampilan Berpikir Kritis dan Hasil Belajar Siswa. Jurnal Pendidikan Vokasi, 4(1): 125-143.

Navi, M. A. 2018. Peningkatan Kompetensi Profesional Guru melalui Penelitian Tindakan Kelas. Jurnal DIMAS, 18(2): 177-194.

Repi, 2019. Meningkatkan Aktivitas dan Hasil Belajar Matematika Siswa dengan Strategi Pembelajaran Berbasis Masalah (Problem-Based Learning) pada Pokok Bahasan Segiempat dan Segitiga di Kelas VI SD Negeri 1 Selat. Jurnal Media Biana Ilmiah, 14(4): 2425-2435.

Rohani \& Farlina, R. 2016. Penerapan Model Problem Based Learning untuk meningkatkan Kemampuan Kognitif Siswa Mata Pelajaran Pendidikan Kewarganegaraan. Edukasi: Jurnal Pendidikan, 14(2): 330-340.

Rubiah, M, 2016. Implementation of Problem-Based Learning Model in Concept Learning Mushroom as A Result of Student Learning Improvement Efforts Guidelines for Teachers. Journal Of Education And Practice, 7(22): 26-30.

Rusman, 2015. Model-Model Pembelajaran: Mengembangkan Profesionalisme Guru, Jakarta: PT Raja Grafindo Persada.

Setyorini, U., Sukiswo, \& Subali, B. 2011. Penerapan Model Problem-Based Learning untuk Meningkatkan Kemampuan Berpikir Kritis Siswa SMP. Jurnal Pendidikan Fisika Indonesia, 7(1): 52-56.

Silaban, E, 2019. Penerapan Pembelajaran Berbasis Masalah untuk Meningkatkan Hasil Belajar Matematika Siswa Kelas XII IPA1 SMA Negeri 1 Rengat Barat pada Semester Genap Tahun Pelajaran 2015/2016. Jurnal Pendidikan Tambusa, 3(1): 66-76. 
Sagor, R. 2004. The Action Research Guidebook, A Four-Step Process for Educators and School Teams. Thousand Oaks, CA: Sage.

Shultz, G. V. \& Li, Y. 2016. Student Development of Information Literacy Skills during Problem-Based Organic Chemistry Laboratory Experiments. Journal of Chemical Education, 93(3): 413-422.

Slameto. 2016. Penyusunan Laporan Tindakan Kelas. Jurnal Scholaria, 6(1): 5473.

Usman, M. U. 2010. Guru Profesional. Bandung: Remaja Rosdakarya.

Vickery, W. L. 2013. Producing and Scrounging during Problem Based Learning. Journal of Problem Based Learning in Higher Education, 1(1): 36-52.

Wolf, M., Kleindienst, M., Ramsauer, C., Zierler, C., \& Winter, E. 2018. Current and Future Industrial Challenges: Demographic Change and Measures for Elderly Workers in Industry 4.0. Journal Annals of the Faculty of Engineering Hunedoara, 16(1): 67-76.

Work, T. \& Mauffette, Y. 2018. Random Allocation of Students into Small Groups in Problem-Based Learning can Create Significant Between-Group Variation during the Assessment Process. Journal of Problem Based Learning in Higer Education, 6(2): 58-70.

Yane, S. 2016. Peningkatan Servis Panjang Bulutangkis melalui Model Problem Based Learning. Jurnal Pendidikan Olahraga, 5(2): 165-174. 